\title{
Research on the Factors of Developing Green Hotels in Resort Hotels
}

\author{
CHIEN-CHUNG YU \\ Graduate School of Business and Operations Management of Chang Jung Christian University, TAIWAN, \\ and Department of Tourism and Recreation Management, Fooyin University, TAIWAN. \\ CHUN-CHU LIU \\ College of Continuing Education \\ Chang Jung Christian University, TAIWAN
}

\begin{abstract}
Taiwan's green mark system has been implemented since 1993. As the "green purchase" clauses are regulated in the government procurement law, Taiwan sets a world precedent and becomes the first state to

legislate to promote "green procurement". The issue arises that leisure hotels face sustainable operation and green energy protection within the climate of reduced customer sources and fierce competition. The paper hence explores three aspects of "purchase, operation and marketing" to evaluate the weight of willingness and decide the priority in association with application of AHP and 12 experts. With the analysis of the AHP, senior executives in the industry expressed there is difficulty in promoting "production history" and "supply chain management". Though recently there have been many food safety incidents in Taiwan, enterprises are pursuing profits instead of emphasizing enterprise social responsibility. In this regard, this study is concerned with how companies pay attention to public issues in business decision-making and contribute to social responsibility despite of reasonable profit-making. This study thus ranks selected indicators and proposes conclusion and suggestion to provide evaluations to the potential green hotel owners.
\end{abstract}

Key-Words: AHP, Brand Equity, Green Marketing, Green Purchase, Resort Hotel, Green Hotel

Received: December 15, 2019. Revised: May 14, 2020. Accepted: May 29, 2020. Published: June 4, 2020.

\section{Introduction}

\subsection{Background}

Along with prosperous and progressive social economy, people inevitably face pressure mentally and physically. As relaxing is necessary, leisure activity play a vital role in daily life. Since fiveworkday system has taken effect in Taiwan, people have more free time for fun. More leisure sites are established so that tourism becomes one of major industries while leisure hotels are prominent choices for accommodation. Green Mark system has been implemented in 1993 so Taiwan is one of advanced green states. Because our Procurement Law takes up green purchase, Taiwan becomes the first state to promote governmental green purchase. Pagiaslis and Krontalis [1] pointed out that green consumption includes consumer knowledge to the environment, the concern for friendly environment, and the belief as well as the action. On the whole, it covers management employs their professional judgment to develop green hotels as one crucial indicator.
This study invited 15 experts to conduct questionnaires, all of whom work in large-scale leisure hotels. They are also well-known in the industry with experiences over 10 years (inclusive). Their personal career experiences are so complete that their sharing is sufficient enough to provide a wealth of information for research. However, these high-level managers are busy at work, and it is not easy to obtain all expert opinions. Finally, the research integrated 12 pieces of opinions. The list of such expert for questionnaires is presented as follows.

\section{Literature Review}

\subsection{AHP Study}

To make complex decision involving uncertain elements, Thomas L. Saaty, a professor at the University of Pittsburg developed a systemic model called analytic hierarchy process (AHP) in 1971. Due to limited ability and time constraints, it is not 
possible to obtain sufficient and related information in real time. Within scenario of risks, disputes and uncertainties, effective decision making and proper assessment require an approach to perform the evaluation and make effective decisions such as development of green hotel. Because those measures consumer recognition, attitude and behavior in terms of green consumption.

\subsection{Motivation}

"Green environment protection" is the universal value nowadays. The common challenge and mission in the 21 st century lie in how to improve energy efficiency, reduce overall energy consumption, balance economic development and environmental protection in order to make win-win between civilized development and natural sustainability. The hospitality industry owners enjoy a good reputation because of green practice, which not only enhances the environmental awareness of the consumer, but also induces the consumer's green consumption concept and attitude in daily life, and ultimately increases their green accommodation willingness [2]. Moreover, hotels should strengthen "green marketing", implement "sustainable environment" and improve "environmental education" to enforce the perception and preference of green hotels and establish a green hotel market positioning [3]. Therefore, this study explores the concept of the leisure hotel industry, the degree of perception in developing green hotels by means of AHP and interviews with the management of leisure hotels.

\subsection{Purpose}

Rex and Baumann [4] indicated that any consumer who has more green consumption value and belief is more willing to buy green products. Consumers have more environmental protection awareness and request higher services and quality, but those green hotels fail to enjoy high accommodation or performance despite their green marks. The promotion of green mark does not prevail around the island because there are only 1160 hotels. Semprebon, Mantovani, Demczuk, Maior and Vilasanti [5] summarized five reasons why people cannot make green consumption including consumer's characteristics and actions, their perceptions and intentions, concern on environment, attitude towards Green Expertise and their behavior control. The study aims to investigate if the draw in management standard coherent in organization [6], the study employs AHP to solve.

The so-called hierarchy is composed of at least two or more layers, and the priority order and weight among the factors relative to the entire hierarchy are calculated. Furthermore, AHP establishes a Consistency Index (CI) and Consi stency Ratio (CR) for all pairs of comparison matrices. Accordingly, the degree of consistency of the entire hierarchy is evaluated. AHP constructs a set of matrices that express relative values between attributes. For example, what is the importance of equipment cost management for this company, and is it easy to operate? They are asked to choose whether the cost is more important, the importance and so on. The eigenvector of each matrix is ranked among the hierarchy factors. The maximum eigenvalue is calculated to decide the relative weights of the alignment matrix $\mathrm{CI}$ as reference indicator for decision making.

One of experts proposed the alternative. The initiatives include commitment to environmental protection, recycle and reuse, improve energy efficiency, water resource use efficiency and protection, green environment, toxic management, supply chain transportation and green purchase.

\subsection{Resort Hotel}

A hotel as a building or facility to offer public accommodation, food and service. The hotels include Commercial Hotel, also known as City Hotel, and Resort Hotel, the latter is the target discussed in the study. Resort hotel mostly is located at a featured town near seaside, mountain, hot spring, scenic and historic site that provides food, beverage, laundry, entertainment such as swimming pool, sauna, gym, chess, and KTV. Some of them also provide golf, ski, horse riding, arrow shooting, diving, cruising and fishing. The importance of green consumption stands out toward hotel development. On one hand, marketing has to display green purchase, and on the other hand, product and service must match green concept [7]. Perera, Auger and Klein [8] indicated that enterprises are encouraged to buy green products to maintain image. People follow the trend and buy products with green mark that are environment friendly. 
Table 1 list of 12 experts

\begin{tabular}{|c|c|c|c|c|c|}
\hline No. & Name & Title & Company & Place & District \\
\hline 1 & Liu Okwang & Vice President & West Lake Resortopia & Miaoli County & North \\
\hline 2 & Lin O wei & Director & Fuli Hot Spring Resort & Nantou County & Central \\
\hline 3 & Pan O han & General & Uni Resort-Kukwang & Taichung City & Central \\
\hline 4 & Dong O chun & General & San Hao International & Yulin County & Central \\
\hline 5 & Chen Ochen & General & Jiannan Resort & Tainan City & South \\
\hline 6 & Lin O hsu & Vice President & Spring Hill Resort & Kaohsiung City & South \\
\hline 7 & Chen Ochia & General & Caesar Park Hotels \& & Pingtung County & South \\
\hline 8 & Pan Oyang & Vice President & Chateau Beach Resort & Pingtung County & South \\
\hline 9 & Hsu Oyen & Director & Yoho Beach Resort & Pingtung County & South \\
\hline 10 & Chang Onan & President & Kenting Maldives Hot & Pingtung County & South \\
\hline 11 & Tseng O tai & Vice President & Uni Resort-Kenting & Pingtung County & South \\
\hline 12 & Hsiang Olung & Director & Kentington Resort & Pingtung County & South \\
\hline Souranger & Manager & Resorts & & \\
\hline
\end{tabular}

Source: compiled by the study

\subsection{Green Hotel}

The development of green marketing has become an important strategy for sustainable business. Prashant Kumar [9] found that the three cores of green marketing are marketing, operation management and sustainable development. Operation management is critical because work planning and execution as well as the business development of each unit in any The variables per AHP are divided into three layers as follows:

(A) the first layer: purchase, operation and marketing construct three aspects to develop green hotels.

(B) the second layer: six factors are developed as procurement principle, procurement action, operation process, management mode, brand equity and purchase perception leading to the 3rd layer.

organization are the basis of the operating phase. In order to create a normal profit-making model for the sharing economy, recycle, reduce, and reuse are the main axes of development principles. According to the Green Hotels Association, Green Hotels are committed to introducing environmentally friendly facilities that save energy, water, solid waste and pollution in addition to saving operating expenses. Yong Joong Kim, Woo Gon Kim, Hyung-Min Choi, and Kullada Phetvaroon [10] pointed out that in the 
service industry, such as hotels, their green efforts include reducing waste, saving energy and water in operations, and educating customers and employees. To protect the environment, Hilton Hotels have established operational goals and policies as well as environmental planning reporting tools to monitor its progress. As a result, Hilton Hotels worldwide reduced its total water consumption by $14.1 \%$ and $14.5 \%$ from 2009-2014. Marriott International also develops green hotels to protect environment.

\section{Methodology and Design}

\subsection{Structure}

The study presents structure according to motivation and purpose after collection and analysis of literature review per figure 1 .

\subsubsection{AHP}

The application of AHP to solve problems encompasses four steps: (1) build a hierarchy, (2) set a pairwise comparison matrix, (3)equate priority vector, (4) calculate maximized eigenvalue.

Consistency comparison matrix $\mathrm{A}$ has the largest eigenvalue $\lambda \max =n$, but the pairwise comparison matrix obtained in the actual evaluation often cannot achieve complete consistency, so the actual comparison matrix is regarded as a slight variation. In this way, $\lambda \max =n$ corresponding to the actual comparison matrix will be close to $\mathrm{n}$; therefore, we can use the difference between $\lambda$ max and $n$ as the criterion of consistency. In the AHP the calculation of $\mathrm{CR}$ is rendered by dividing CI by R.I. If $\mathrm{CR} \leqq 0.1$, the consistency can be regarded satisfactory.

\subsubsection{Framework of AHP hierarchy}

The study intends to display key factors of developing green hotels in resort hotels. With AHP, the problems turn into hierarchy and further develop the importance, priority and difference of key factors.

(C) the third layer: 16 factors are rendered as production $\mathrm{CV}$, cost, expense under "procurement principle"; supply chain management, cost rate control, expense rate control under "procurement action"; unit work planning and unit work development under "operation process"; compliance and persistence under "management mode"; corporate image, brand loyalty, brand awareness under "brand equity"; perceived quality, price and risk under "purchase perception."

\subsection{AHP Hypothesis}

The hypothesis results from factors and their descriptions are detailed as table 2 .

\section{Results \\ 4.1 AHP description}

When the leisure hotel industry faces the rise of the green hotel, the management has a lot of considerations that are relatively complicated and difficult to choose. This study used AHP to integrate opinions by current experts in resort hotel (see Table $3)$. The first consideration counts on "operation aspect". The "brand equity" is the first important factor on the second layer, and the "management mode" and "operation process" are respectively the second and the third. And the "Persistence" under the "management mode" tops the 16 key indicators, and the "corporate image" under the "brand equity" has the second place. Most of the high-level managers have the interests of the company as the main consideration in decision-making.

\section{4-2 Analysis}

The study focuses on factors in developing green hotels. In sum, the following are the results agreed by the hotel management as guideline:

- procurement principle: concern on cost, expense and production $\mathrm{CV}$ to develop green hotel.

- procurement action : manage supply chain, reduce cost and expense to develop green hotel.

- operation process : implement smooth process and internal development to develop green hotel.

- management mode : be sure about support by employees and company to develop green hotel. 


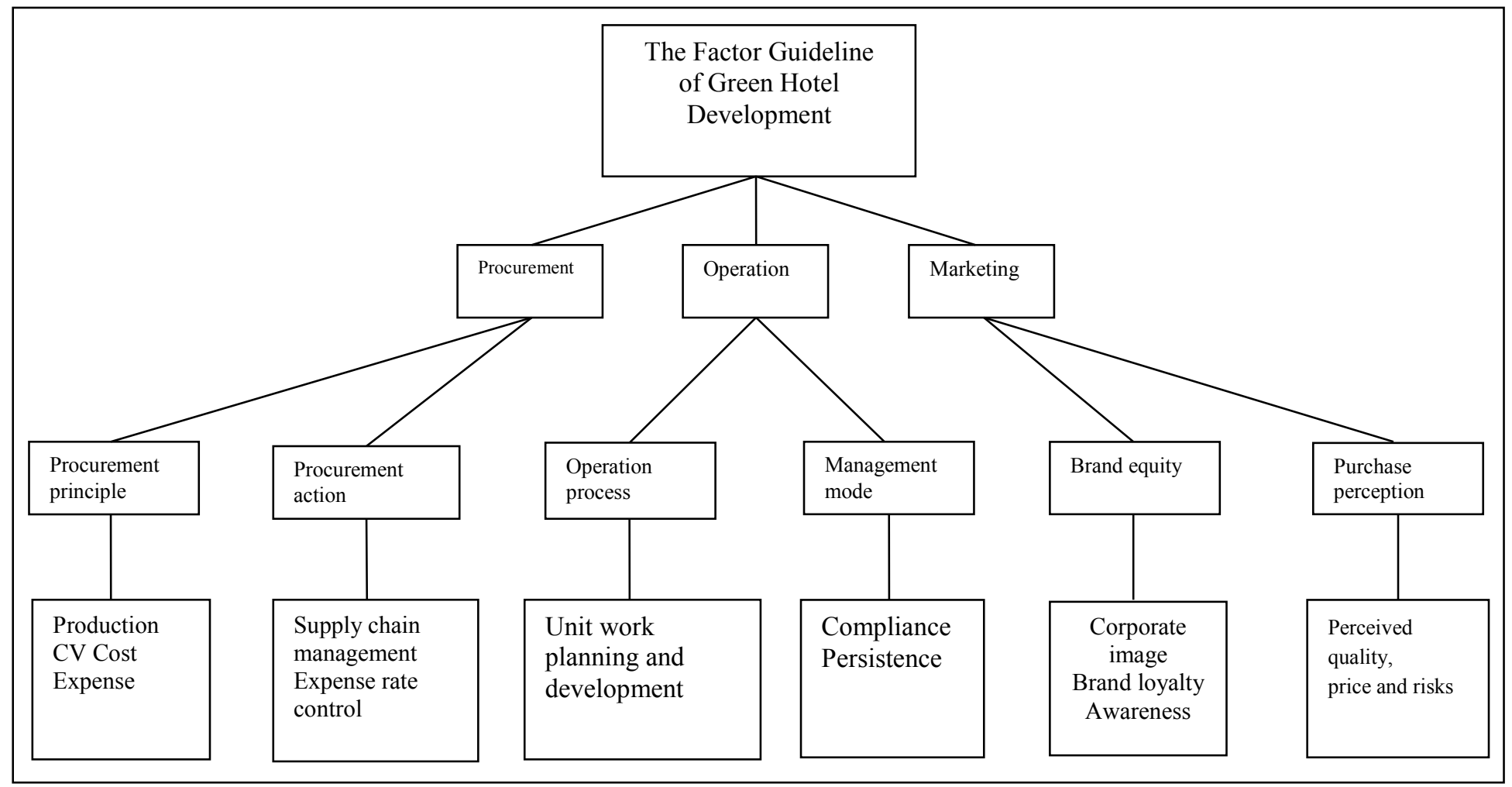

Figure 1 the factor guideline of green hotel development - AHP hierarchy 
Table 2 factors by AHP

\begin{tabular}{|c|c|c|}
\hline $\begin{array}{l}\text { The first layer } \\
\text { factor }\end{array}$ & $\begin{array}{l}\text { The second layer } \\
\text { factor }\end{array}$ & The third layer factor \\
\hline \multirow{6}{*}{$\begin{array}{l}\text { Procurement } \\
\text { aspect }(\mathrm{A}-1)\end{array}$} & \multirow{3}{*}{$\begin{array}{l}\text { Procurement } \\
\text { principle (B-1) }\end{array}$} & $\begin{array}{l}\text { Production } \mathrm{CV} \text { - procured material \& goods are equipped with } \\
\text { production or source } \mathrm{CV} \circ(\mathrm{C} 1-1)\end{array}$ \\
\hline & & $\begin{array}{l}\text { Cost consideration - if the cost increase due to green hotel (C1- } \\
\text { 2) }\end{array}$ \\
\hline & & $\begin{array}{l}\text { Expense consideration - if the expense increase due to green } \\
\text { hotel }(\mathrm{C} 1-3)\end{array}$ \\
\hline & \multirow{3}{*}{$\begin{array}{l}\text { Procurement } \\
\text { action(B-2) }\end{array}$} & $\begin{array}{l}\text { Supply chain management - if the capacity to plan and execute } \\
\text { supply chain exist (C2-1) }\end{array}$ \\
\hline & & $\begin{array}{l}\text { Cost control - if the expense decrease due to green control (C2- } \\
\text { 2) }\end{array}$ \\
\hline & & $\begin{array}{l}\text { Expense control-if the control decrease due to green control } \\
(\mathrm{C} 2-3)\end{array}$ \\
\hline \multirow{4}{*}{$\begin{array}{l}\text { Operation } \\
\text { aspect(A-2) }\end{array}$} & \multirow{2}{*}{$\begin{array}{l}\text { Operation } \\
\text { process(B-3) }\end{array}$} & $\begin{array}{l}\text { Unit work planning - if unit work becomes trivial due to green } \\
\text { hotel (C3-1) }\end{array}$ \\
\hline & & $\begin{array}{l}\text { Unit business development - if unit has disputes due to green } \\
\text { hotel(C3-2)。 }\end{array}$ \\
\hline & \multirow{2}{*}{$\begin{array}{l}\text { Management } \\
\text { mode(B-4) }\end{array}$} & $\begin{array}{l}\text { compliance - if employees comply with work and support in } \\
\text { association with green hotel(C4-1) }\end{array}$ \\
\hline & & $\begin{array}{l}\text { persistence }- \text { if enterprises persist to execute green hotel } \\
\text { requirements }(\mathrm{C} 4-2)\end{array}$ \\
\hline \multirow{6}{*}{$\begin{array}{l}\text { Marketing } \\
\text { aspect(A-3) }\end{array}$} & \multirow{3}{*}{ Brand equity(B-5) } & $\begin{array}{l}\text { Corporation image - if customers support corporate social } \\
\text { responsibility }(\mathrm{C} 5-1)\end{array}$ \\
\hline & & $\begin{array}{l}\text { Brand loyalty - if customers support corporate services and } \\
\text { products }(\mathrm{C} 5-2)\end{array}$ \\
\hline & & $\begin{array}{l}\text { Brand awareness - if customers support corporate reputation } \\
\text { (C5-3) }\end{array}$ \\
\hline & \multirow{3}{*}{$\begin{array}{c}\text { Purchase } \\
\text { perception (B-6) }\end{array}$} & $\begin{array}{l}\text { Perceived quality - if customers perceive corporate service } \\
\text { quality and accept (C6-1) }\end{array}$ \\
\hline & & $\begin{array}{l}\text { Perceived price - if customers perceive corporate price and } \\
\text { accept (C6-2) }\end{array}$ \\
\hline & & Perceived risk - if customers perceive corporate to trust (C6-3) \\
\hline
\end{tabular}

- brand equity : establish corporate identity, brand loyalty and fame to develop green hotel.

- purchase perception : evaluate consumer toward service quality, price and trust to develop green hotel.

\section{Conclusion and Suggestion}

\subsection{Conclusion}

The selected criteria evaluated by 12 resort hotel experts can be a good reference basis and sharing to the leisure hotel industry in the future regarding the 
Table 3 AHP analysis by 12 experts

\begin{tabular}{|c|c|c|c|c|c|c|c|c|}
\hline \multicolumn{3}{|c|}{ First layer $(\mathrm{n}=3)$} & \multicolumn{3}{|c|}{ Second layer $(n=6)$} & \multicolumn{3}{|l|}{ Third layer $(n=16)$} \\
\hline Indicator & Weight & Rank & Indicator & Weight & Rank & Indicator & Weight & Rank \\
\hline \multirow{6}{*}{ Procurement } & \multirow{6}{*}{0.271} & \multirow{6}{*}{2} & \multirow{3}{*}{$\begin{array}{l}\text { Procurement } \\
\text { principle }\end{array}$} & \multirow{3}{*}{0.1168} & \multirow{3}{*}{6} & Production CV & 0.0382 & 13 \\
\hline & & & & & & Cost & 0.0476 & 11 \\
\hline & & & & & & Expense & 0.0309 & 15 \\
\hline & & & \multirow{3}{*}{$\begin{array}{l}\text { Procurement } \\
\text { action }\end{array}$} & \multirow{3}{*}{0.1347} & \multirow{3}{*}{4} & Supply chain management & 0.0572 & 8 \\
\hline & & & & & & Cost rate control & 0.0418 & 12 \\
\hline & & & & & & Expense rate control & 0.0357 & 14 \\
\hline \multirow{4}{*}{ Operation } & \multirow{4}{*}{0.485} & \multirow{4}{*}{1} & \multirow{2}{*}{$\begin{array}{l}\text { Operation } \\
\text { process }\end{array}$} & \multirow{2}{*}{0.1698} & \multirow{2}{*}{3} & Unit work planning & 0.0793 & 5 \\
\hline & & & & & & Unit work development & 0.0905 & 3 \\
\hline & & & \multirow{2}{*}{$\begin{array}{l}\text { Management } \\
\text { mode }\end{array}$} & \multirow{2}{*}{0.1952} & \multirow{2}{*}{2} & compliance & 0.0740 & 6 \\
\hline & & & & & & persistence & 0.1213 & 1 \\
\hline \multirow{6}{*}{ Marketing } & \multirow{6}{*}{0.243} & \multirow{6}{*}{3} & \multirow{3}{*}{ Brand equity } & \multirow{3}{*}{0.2601} & \multirow{3}{*}{1} & Corporate image & 0.1092 & 2 \\
\hline & & & & & & Brand loyalty & 0.0810 & 4 \\
\hline & & & & & & Brand recognition & 0.0698 & 7 \\
\hline & & & \multirow{3}{*}{$\begin{array}{l}\text { Purchase } \\
\text { perception }\end{array}$} & \multirow{3}{*}{0.1235} & \multirow{3}{*}{5} & Perceived quality & 0.0482 & 10 \\
\hline & & & & & & Perceived price & 0.0246 & 16 \\
\hline & & & & & & Perceived risk & 0.0507 & 9 \\
\hline
\end{tabular}


green marketing issues. While using AHP to research, it is found that it has problems with promotion of "production history" and "supply chain management". Even there have been many food safety incidents in Taiwan in recent years, enterprises are still aiming at profit-seeking rather than considering social responsibility. This research is concerned with how companies care about public issues in business decision-making, and do their part for social responsibility in creating reasonable profits. If green energy environmental issues are slogans, the government and enterprises must actively continue to create a healthy, safe, the government and enterprises must actively continue to create a healthy, safe, fortunate, happy and carefree living environment in Taiwan.

\subsection{Suggestion}

The experts in this research still serve in the industry. It is not easy for them to provide analysis guidelines in their busy schedule. This study intended to analyze resort hotels in North, Central and South to make certain reliability and validity. In the end, only 12 experts' opinions were collected for analysis. Therefore, the research gap comes across lesser samples in the North and Central. Hualien and Taitung shall be included for further research. Moreover, other types of restaurants or enterprises can conduct sampling of this topic. Relevant research can be provided to the government as a green energy $\mathrm{p}$ o

(1)

\section{References}

[1] Pagiaslis, A. \& Krontalis, A. K., Green (2014), consumption behavior antecedents: environmental concern, knowledge, and beliefs, Psychology and Marketing, 31(5), 335-348.

[2] Han, H., \& Yoon, H. J. (2015), Hotel customers' environmentally responsible behavioral intention: Impact of key constructs on decision in green consumerism. International Journal of Hospitality Management, 45, 22-23.

[3] Baker, M. A., Davis, E. A., and Weaver, P. A. (2014), Eco-friendly Attitudes, Barriers to Participation, and Differences in Behavior at Green Hotels, Cornell Hospitality Quarterly, 55(1), 89-99.

[4] Rex, E., \& Baumann, H. (2007), Beyond ecolabels: what green marketing can learn from conventional marketing. Journal of cleaner production, 15(6), 567-576.

[5] Semprebon, E., Mantovani, D., Demczuk, R., Maior, C. S., \& Vilasanti, V. (2018), Green consumption: a network analysis in marketing. Marketing Intelligence \& Planning, https://doi.org/10.1108/MIP-12-2017-0352.

[6] Ray W. (2012), The investigation of Green Best Practices for Hotels in Taiwan. International Conference on Asia Pacific Business Innovation and Technology Management. Procedia - Social and Behavioral Sciences, 57, 140-145.

[7] Aasha Sharma and Cyril Foropon (2019), Green product attributes and green purchase behavior: A theory of planned behavior perspective with implications for circular economy. Management Decision, 57(4), 2019, pp.1018-1042. Emerald Publishing Limited 0025-1747 DOI 10.1108/MD10-2018-1092 
[8] Perera, C., Auger, P., \& Klein, J. (2018). Green consumption practices among young environmentalists: a practice theory perspective. Journal of Business Ethics, 152(3),843-864.

[9] Christopher Groening, and Qingyun Zhu (2018), Green marketing consumer-level theory review: A compendium of applied theories and further research directions, ournal of Cleaner Production 172(2), 1848-1866

[10] Yong Joong Kim; Woo Gon Kim; Hyung-Min Choi; Kullada Phetvaroon (2019), The effect of green human resource management on hotel employees' ecofriendly behavior and environmental performance. International Journal of Hospitality Management, 76, 83-93.

\section{Creative Commons Attribution License 4.0 (Attribution 4.0 International, CC BY 4.0)}

This article is published under the terms of the Creative Commons Attribution License 4.0

https://creativecommons.org/licenses/by/4.0/deed.en_US 